\title{
Feeding behavior and activity period of three Neotropical bat species (Chiroptera: Phyllostomidae) on Musa paradisiaca inflorescences (Zingiberales: Musaceae)
}

\author{
Ayesha R. Pedrozo' (D), Luiz A. C. Gomes² (D) \& Wilson Uieda ${ }^{3}$ (D)
}

\footnotetext{
1. Laboratório de Ecologia de Mamíferos, Departamento de Ecologia, Universidade do Estado do Rio de Janeiro, Rua São Francisco Xavier, 524, $20559-900$ Rio de Janeiro, RJ, Brazil. (ayesha.ribeiro@gmail.com)

2. Laboratório de Mastozoologia, Departamento de Biologia Animal, Instituto de Ciências Biológicas e da Saúde, Universidade Federal Rural do Rio de Janeiro, BR-465, Km 7, 23890-000 Seropédica, RJ, Brazil. (luizantoniocg@gmail.com)

3. Departamento de Zoologia, Instituto de Biociências, Universidade Estadual Paulista "Júlio de Mesquita Filho", Rua Prof. Dr. Antônio Celso Wagner Zanin, 250, 18618-689 Botucatu, SP, Brazil. (wuieda@hotmail.com)
}

Received 4 November 2017

Accepted 26 April 2018

Published 21 June 2018

DOI: $10.1590 / 1678-4766 e 2018022$

\begin{abstract}
We studied the feeding behavior and the activity period of three phyllostomid bat species on Musa paradisiaca inflorescences in an orchard located in southeastern Brazil. Glossophaga soricina (Pallas, 1766), Anoura caudifer (É. Geoffroy, 1818), and Phyllostomus discolor (Wagner, 1843) were frequently observed, videotaped, and mist-netted visiting banana inflorescences. Three approaching strategies on banana inflorescences were performed by bats: hovering (glossophagine species), upside landing (G. soricina), and downside landing (P. discolor). A new feeding behavior that consisted in hovering and licking the nectar that dripped from the distal part of a closed bract was observed for glossophagines. Visits occurred throughout the night (from 18:00 h to 05:00 h). However, activity pattern of nectarivorous bat species was significantly different from the omnivorous bat species, with the formers presenting visiting peaks at 21:00 hs and 23:30 hs, and the second at 23:45 hs and 02:30 hs. Dietary specialization, body size, and foraging behavior are important features that are linked to kind of approaching strategies to flowers and activity period of bats. Although bat visits on $M$. paradisiaca inflorescences are not reproductively important to banana plant, its nectar is a frequent and abundant food source for bats from the family Phyllostomidae, at least in Southeastern Brazil.
\end{abstract}

KEYWORDS. Approaching strategies, banana flowers, nectarivorous bats, omnivorous bat, Southeastern Brazil

RESUMO. Comportamento alimentar e período de atividade de três espécies de morcegos neotropicais (Chiroptera: Phyllostomidae) sobre inflorescências de Musa paradisiaca (Zingiberales: Musaceae). Nós estudamos o comportamento alimentar e o período de atividade de três espécies de morcegos filostomídeos sobre as inflorescências de Musa paradisiaca em um pomar no sudeste do Brasil. Glossophaga soricina (Pallas, 1766), Anoura caudifer (É. Geoffroy, 1818) e Phyllostomus discolor (Wagner, 1843) foram frequentemente observados, filmados e capturados com redes de neblina visitando as inflorescências de banana. Três estratégias de abordagens as inflorescências de banana foram realizadas pelos morcegos: o adejo (espécies glossofagíneas), o pouso de cabeça para cima ( $G$. soricina) e o pouso de cabeça para baixo ( $P$. discolor). Um novo comportamento alimentar que consistiu em adejar e lamber o néctar que gotejava da parte distal de uma bráctea fechada foi observado para glossophagíneos. As visitas ocorreram ao longo de toda noite (das 18:00 hs às 05:00 hs). No entanto, o período de atividade das espécies de morcegos nectarívoros foi significativamente diferente da espécie de morcego onívoro, com as primeiras apresentando picos de visitação às 21:00 hs e às 23:30 hs, e a onívora, às 23:45 hs e às 02:30 hs. A especialização na dieta, o tamanho corporal e o comportamento de forrageio são importantes características que estão relacionadas ao tipo de estratégia de abordagem às flores e ao período de atividade dos morcegos. Embora as visitas dos morcegos às inflorescências de $M$. paradisiaca não sejam reprodutivamente importantes para esta planta, seu néctar é um recurso alimentar frequente e abundante para os morcegos da família Phyllostomidae, ao menos na região sudeste do Brasil.

PALAVRAS-CHAVE. Estratégias de abordagem, flores de bananeiras, morcegos nectarívoros, morcego onívoro, sudeste do Brasil.

Diverse plants have morphological and physical features that are associated with the feeding behavior of bats that visit and pollinate their flowers (BAKER, 1961; TSCHAPKA $\&$ DressLER, 2002). The interaction between bats and these plants (BAKER, 1961) is an outcome of long evolutional process of plants to attract nocturnal visitors (FLEMING et $a l ., 2009)$ and has been observed for species of the genus Musa (Musaceae) (Itino et al., 1991; Elangovan et al.,
2000; LiU et al., 2002; MuRPHY et al., 2016). This genus has many features in its inflorescences, such as large size, visibility, floral aroma, and abundant nectar, which make it an important food resource for both diurnal and nocturnal animals (NUR, 1976; FAEGRI \& VAN DER PIJL, 1979; ITINO et al., 1991; ENDRESS, 1995; ElANGOVAN et al., 2000; LiU et al., 2002). Banana plants with erect inflorescences are visited by birds, whereas those with pendant inflorescences are visited 
by bats (LIU et al., 2002). Furthermore, nectarivorous bats use open bracts as acoustic beacons to find the exact location of nectar through the echolocation (MURPHY et al., 2016).

Phyllostomidae is the most diversified bat family in the Neotropical region due to its higher species richness, number of feeding habits, and variation in body size (CARValho, 1961; Gardner, 1977, 2007). Nectarivory is found in many phyllostomid species even those that not feed mainly on nectar (e.g. BREDT et al., 2012). For example, Anoura caudifer (É. Geoffroy, 1818), Anoura geoffroyi Gray, 1838, Glossophaga longirostris Miller, 1898, Glossophaga soricina (Pallas, 1766) (subfamily Glossophaginae) and Lonchophylla bokermanni Sazima, Vizotto \& Tadei, 1978 (subfamily Lonchophyllinae) are specialized in high degree of nectarivory, while the omnivorous species Phyllostomus discolor (Wagner, 1843) and Phyllostomus elongatus (É. Geoffroy, 1810) (subfamily Phyllostominae) feed opportunistically on nectar (GARDNER, 1977; BREDT et al., 2012). In this sense, bats can use the same food source, however, in different ways (HeIthaus et al., 1975) in time and space (FISCHER, 1992) in order to avoid competition (PiAnKa, 1973; Muller \& ReIs, 1992). Moreover, body size of species can determine how these animals approach the nectar (HeITHAUs et al., 1974; FISCHER, 1992), with larger species $(>15 \mathrm{~g})$ generally landing on the flower and smaller species $(<15 \mathrm{~g})$ hovering on it (e.g. HeITHaus et al., 1974; Silva \& PERACCHI, 1999).

Nectar-feeding bats tend to visit flowers with higher frequency than non-nectar feeding bats which have no morphological adaptations to nectarivory (e.g. SAZIMA \& SAZIMA, 1978; TschapKa \& Dressler, 2002). These visits can be affected by the amount of available nectar in each flower that can increase the territoriality of bats when nectar is a limiting resource (e.g. LeMKe, 1984) and favor species according to their morphological specialization (GONZALEZ-TERRAZAS et al., 2012) and nectar extraction mechanism (TsCHAPKA et al., 2015). Bats with tongue with long hairlike papillae are more efficient in extracting small and distributed nectar amounts, whereas bats with tongue with lateral grooves are more efficient in extracting nectar deeper levels in flowers (TsCHAPKA et al., 2015). Conversely, bats with no morphological specialization to nectarivory tend to visit plant species with flowers that have easy access and provide large amounts of nectar (GIANNINI \& BRENES, 2001).

In southeastern Brazil, bats use an orchard to forage and eat (PEDrozo et al., 2016). In the present study, from observations of bat species feeding on nectar of Musa paradisiaca $\mathrm{L}$. in this orchard, we investigated the feeding behavior of three Neotropical bat species: the nectarivorous Anoura caudifer and Glossophaga soricina, and the omnivorous Phyllostomus discolor. The goal herein was to analyze whether there are differences among approaching strategies and activity period of these three species during the visits to banana inflorescences. We expected that these three bat species present different approaching strategies to banana inflorescence due to their different dietary specialization levels and body mass (e.g. Heithaus et al., 1974; Sazima \&
SAZIMA, 1977; LemKe, 1984). Moreover, because nectar is the main food in diet of the nectar-feeding bats, we expected that they perform more visits and visit sooner the inflorescences than $P$. discolor throughout the night (e.g. Heithaus et al., 1974; Aguiar \& Marinho-Filho, 2004).

\section{MATERIAL AND METHODS}

This study was carried out in an orchard at Santo Antônio dos Ipês Farm (22 $18^{\prime} 22^{\prime}$ 'S, 48 32'06”W) in the Municipality of Jaú, state of São Paulo (Southeastern Brazil), at approximately $500 \mathrm{~m}$ asl. The farm has permanent crops of oranges, peaches, and coffee, a silo for storing coffee beans, and the Amadeu Botelho Ecological Reserve (a Semideciduous Seasonal Forest remnant) (Pedrozo et al., 2016).The orchard has fruit plants, such as banana [M. paradisiaca], jabuticaba [Plinia trunciflora (O. Berg) Kausel, Myrtaceae], guava [Psidium guajava L., Myrtaceae], orange [Citrus sp., Rutaceae], lime [Citrus limon (L.) Osbeck, Rutaceae], and mango [Mangifera indica L., Anacardiaceae]. In the orchard, there were 11 groups of banana plants, each one comprising from three to five plants, which were irregularly and mainly distributed on the edges of a trail of $160 \mathrm{~m}$ in length. Each plant had an inflorescence located at approximately $2 \mathrm{~m}$ in height. The observed inflorescences of M. paradisiaca had 13 flowers arranged linearly under each reddish bract and, as well as other Musa species, anthesis is indicated by the opening of the bract, which occurs from the base to the apex of the inflorescence (ITINO et al., 1991).

Five samplings were performed between January 2010 and July 2011 to survey the bat species in the orchard. The samplings were conducted using eight mist nets near the banana plants that were opened just before sunset and closed six hours later. The captures were preferentially performed during the nights with new moon to maximize the bat captures (ESBÉRARD, 2007). Bats were placed in cotton bags where remained until the end of sampling hour and mist nets had been closed. After that, individuals were identified according to specific literature (GARDNER, 2007), sexed, measured (forearm in mm and body mass in $\mathrm{g}$ ), and released at same night and place.

Five nights of direct observations and four nights of videotaping were performed between June and July 2011. Musa paradisiaca inflorescences with high number of new flowers and open bracts were selected. Direct observation of bat visiting behavior to inflorescences was studied using night vision binoculars, records with a photographic camera and images recorded using a video camera (Sony DCRTRV310) equipped with an infrared light source and placed on a tripod. Each direct observation session lasted from two to four hours and was performed at different times in each night in order to cover the entire night hours. Videotaping sessions were performed through the aforementioned video camera and each videotaping session lasted $12 \mathrm{hs}$ (from sunset to sunrise), totaling $48 \mathrm{hs}$. Two inflorescences were analyzed by night: a) one to analyze direct observation bat approaching behavior to banana plant, flights around the 
banana plant, solitary or group flights, and body size of bats (large bats represented by the Phylostomidae or small bats represented by the Glossophaginae); and b) other to analyze the videotaping of approaching behavior to female flowers, visiting behavior, visiting times, and frequency of visits. Bat species were identified based on the analysis of photographic images and the examination of the mist-netted bats (see PeDrozo et al., 2016, for details of mist-netting in the study area).

Because $A$. caudifer and $G$. soricina did not can be reliably distinguished in videos and for being small $(11 \pm$ $0.45 \mathrm{~g}$ and $10 \pm 1.18 \mathrm{~g}$ respectively), closely related and both ecologically and morphologically similar species (AGUIAR \& MARINHO-FILHO, 2004; GARDNER, 2007), they were pooled and treated as "glossophagines" in bat activity period section. Thus, the nonparametric Mardia-Watson-Wheeler (W) test was used to test whether the glossophagines visit sooner the inflorescences than $P$. discolor throughout the night. Prior to this test, abnormality and heteroscedasticity of the data were tested using the Shapiro-Wilk test $(p<0.001)$ and Levene's test ( $p<0.001)$, respectively, executed on the Past 2.02 software (HAMmer et al., 2001). W test was executed using the Oriana 4.0 software (KovACH, 2011). The level of significance was set at $5 \%(\mathrm{p} \leq 0.05)$. Only data from videos were used to analyze bat activity period. Data from direct observations were exclusively used to describe the bat approaching strategies to the inflorescences.

\section{RESULTS}

Eight species, all belonging to the family Phyllostomidae, were mist-netted in the orchard: the nectarivorous $A$. caudifer $(n=8)$ and $G$. soricina $(n=12)$ (Glossophaginae), the frugivorous Carollia perspicillata (Linnaeus, 1758) $(n=6)$ (Carolliinae), Artibeus lituratus (Olfers, 1818) ( $n=134)$, Platyrrhinus lineatus (É. Geoffroy, 1810) $(n=12)$ and Sturnira lilium (É. Geoffroy, 1810) $(n$ $=40)$ (Stenodermatinae), and the omnivorous $P$. discolor $(n=29)$ and Phyllostomus hastatus (Pallas, 1767) $(n=1)$ (Phyllostominae). However, only A. caudifer, G. soricina and $P$. discolor were photographed and videotaped visiting banana inflorescences in the orchard. Nectarivorous species were recorded in all four videotaping nights and $P$. discolor was recorded in three nights.

Both glossophagine species performed flights around the plants during their approaches on banana inflorescences, whereas $P$. discolor habitually flew directly on inflorescences. Three approaching behaviors were observed: (1) hovering, (2) upside landing, and (3) downside landing. The hovering strategy (Fig. 1): bat flew towards inflorescence, hovered for less than a second in front of a flower while inserting its snout and long tongue into the flower and, then, turned its body to one side and flew away. In photo analysis, hovering behavior was recorded for both $A$. caudifer and $G$. soricina. On 23 June 2011, a new feeding behavior was observed to glossophagine bat that consisted in hovering and licking the nectar near the distal portion of closed bracts. Nectar come from available flowers of open bracts, run on the closed bracts and dripped in the distal portion of closed bracts. This kind of behavior was observed nine times between 01:00 $\mathrm{h}$ and 01:45 h. Upside landing strategy (Fig. 2): bat flew towards inflorescence, landed on with its head turned upward and wings folded alongside the body, held the closed bracts with the aid of its thumb nails (with or without supporting its feet on the lower bract) and inserted its snout inside a flower. This landing behavior lasted from two to five seconds and was only observed for G. soricina. With this strategy, bats habitually explore more than one flower of the same inflorescence and in a single visit. Downside landing strategy (Fig. 3): bat flew towards inflorescence and landed on an open bract above the flowers, holding itself on the stem of the inflorescence with the aid of its feet. Its head was positioned in direction of the flowers and ventral region was supported on the open and closed bracts. The wings remained open and turned backward and bat inserted its snout into the flower. After feeding, bat flew away. The visit lasted approximately three seconds and bat was seen inserting its snout into four or five flowers of the same inflorescence and in a single visit. Downside landing strategy was only observed for $P$. discolor.

Four videotaping nights of five inflorescences ( $n$ $=65$ available flowers) of different banana plants were performed in July 2011. All bats performed solitary flights. Glossophagines performed 608 visits of which $65 \%$ were of the hovering strategy. The other $35 \%$ of Glossophagine visits were performed using the upside landing strategy that was observed only in G. soricina. Phyllostomus discolor did 102 visits through the downside landing strategy. In general, the first visits were observed at the onset of nightfall (approximately 18:00 hs) and the last visits were observed just before dawn (approximately 05:00 hs). Despite having some overlapping in their visits, Glossophagines and $P$. discolor presented different occurrence peaks throughout the night ( $\mathrm{W}=30.514, \mathrm{p}<0.001$; Fig. 4A). Glossophagines had two great visiting peaks that occurred in the first part of the night: the first at around 21:00 hs and the second at around 23:30 hs. Hovering strategy presented a peak at around 23:00 hs, whereas upside landing had two peaks, at around 21:00 hs and 23:00 hs. However, there was no evident difference between the hovering and upside landing performed by the glossophagines (Fig. 4B). Phyllostomus discolor also showed two great peaks, the first at around 23:45 hs and the second, however, in the second part of the night, at around 02:30 hs. Only solitary visits were observed.

\section{DISCUSSION}

Three visiting strategies to $M$. paradisiaca inflorescences by three Neotropical bat species were observed in the present study: hovering, upside landing, and downside landing. Bat approaching strategies to flowers are directly related to size and body mass of bats, accessibility to flowers, and dietary specialization (HeIthaus et al., 1975; Gould, 1978; Silva \& PeracCHI, 1999; GianNini \& BRENES, 2001). Herein, glossophagine species (A. caudifer and G. soricina) 


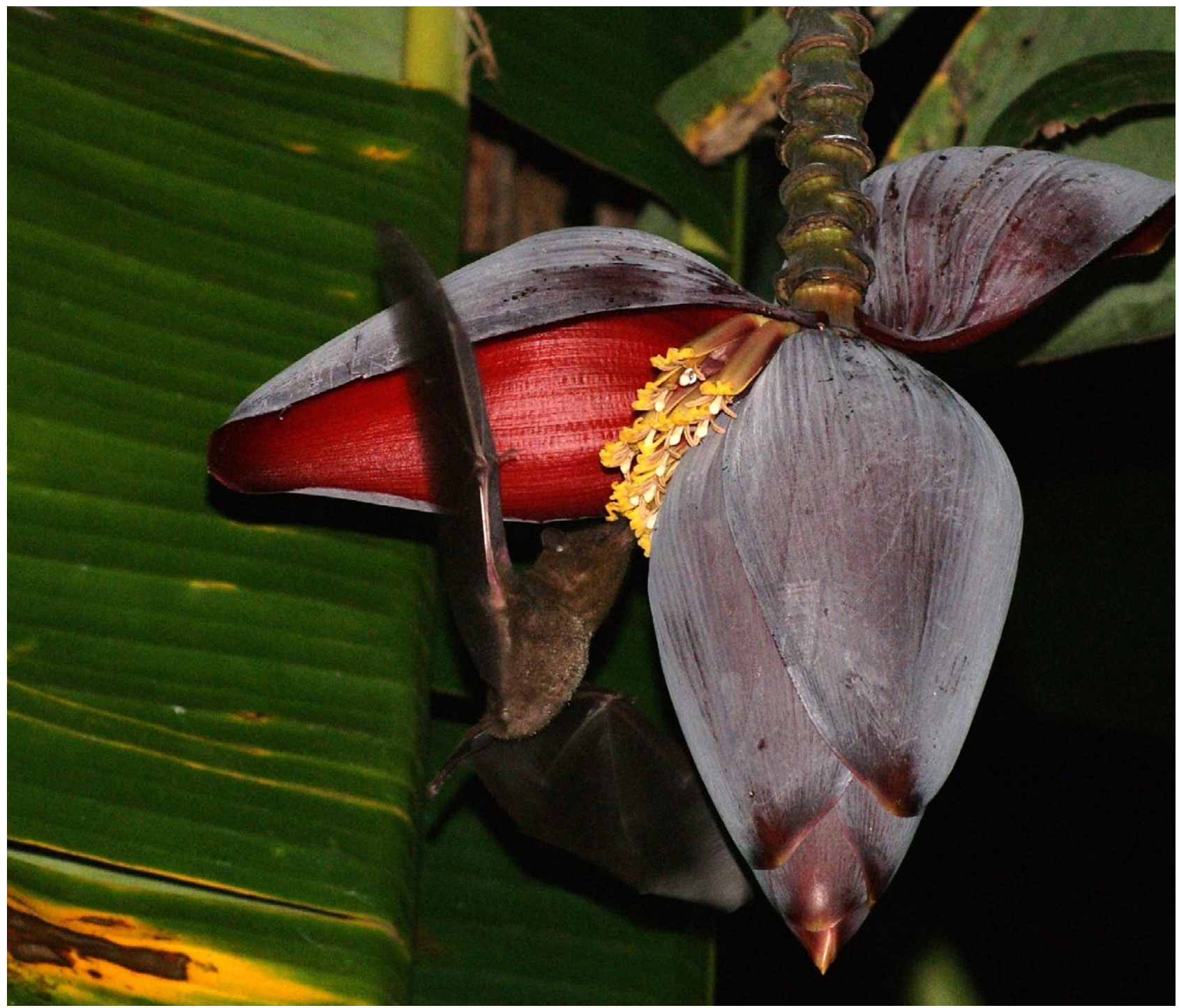

Fig. 1. Anoura caudifer (É. Geoffroy, 1818) with its snout partially inserted in floral tube performing the hovering strategy on the banana inflorescence in an orchard located in the state of São Paulo, Brazil. Photo: Wilson Uieda.

often employed hovering strategy that was used in $65 \%$ of their visits to banana inflorescences. In the Neotropical region, this behavior is typically observed among nectarivorous bat species that have small body mass $(<30 \mathrm{~g})$ and belong to Glossophaginae and Lonchophyllinae (Phyllostomidae) (TsCHAPKA \& DresSLER, 2002; FLEMING et al., 2009). Species from these subfamilies have morphological adaptations to nectarivory such as elongated rostrum, long tongue with long papillae or lateral grooves, and reduced dentition (TSCHAPKA \& DRESSLER, 2002). Hovering behavior is also seen in large Old Word specialized nectar-feeding bats (up to $82 \mathrm{~g}$ ) (subfamily Macroglossinae, Pteropodidae) and, in some cases, in fruit-feeding bats [e.g. Cynopterus sphinx (Vahl, 1797), Pteropodidae] (Elangovan et al., 2000). However, these bats do not use this behavior to extract nectar, they only perform brief hovering bout to recognize the flower before landing on it (FLEMING et al., 2009). According to GIANNINI \& BRENES (2001), small body mass, wing loading, arm wings, and large and rounded wingtips are aerodynamic features that facilitate hovering performance. This array of features may explain why most non-nectar-feeding bats, as $P$. hastatus in the present study, did not perform this strategy. Hovering strategy seems to be an advantageous behavior for nectarivorous bats, because this behavior can be a rapid way to escape from potential predators (MURPHY et al., 2016), such as opossums and small felines, or even a way to monopolize the nectar (flowers) keeping themselves in front of food source in relation to other nectar-feeding bats (TsCHAPKA, 2003). Bats that perform this approaching behavior are efficient foragers, considering the amount of consumed nectar (GonZalez-TERRAZAS et al., 2012) in relation to their body mass (GIANNINI \& BRENES, 2001; WINTER \& VON HELVERSEN, 2003).

In the present study, although glossophagines have often shown hovering strategy on banana inflorescences, they still used the upside landing strategy. LEMKE (1984) observed that the type of approaching used on flowers by nectar-feeding bats rely on the flower morphology of plants, 


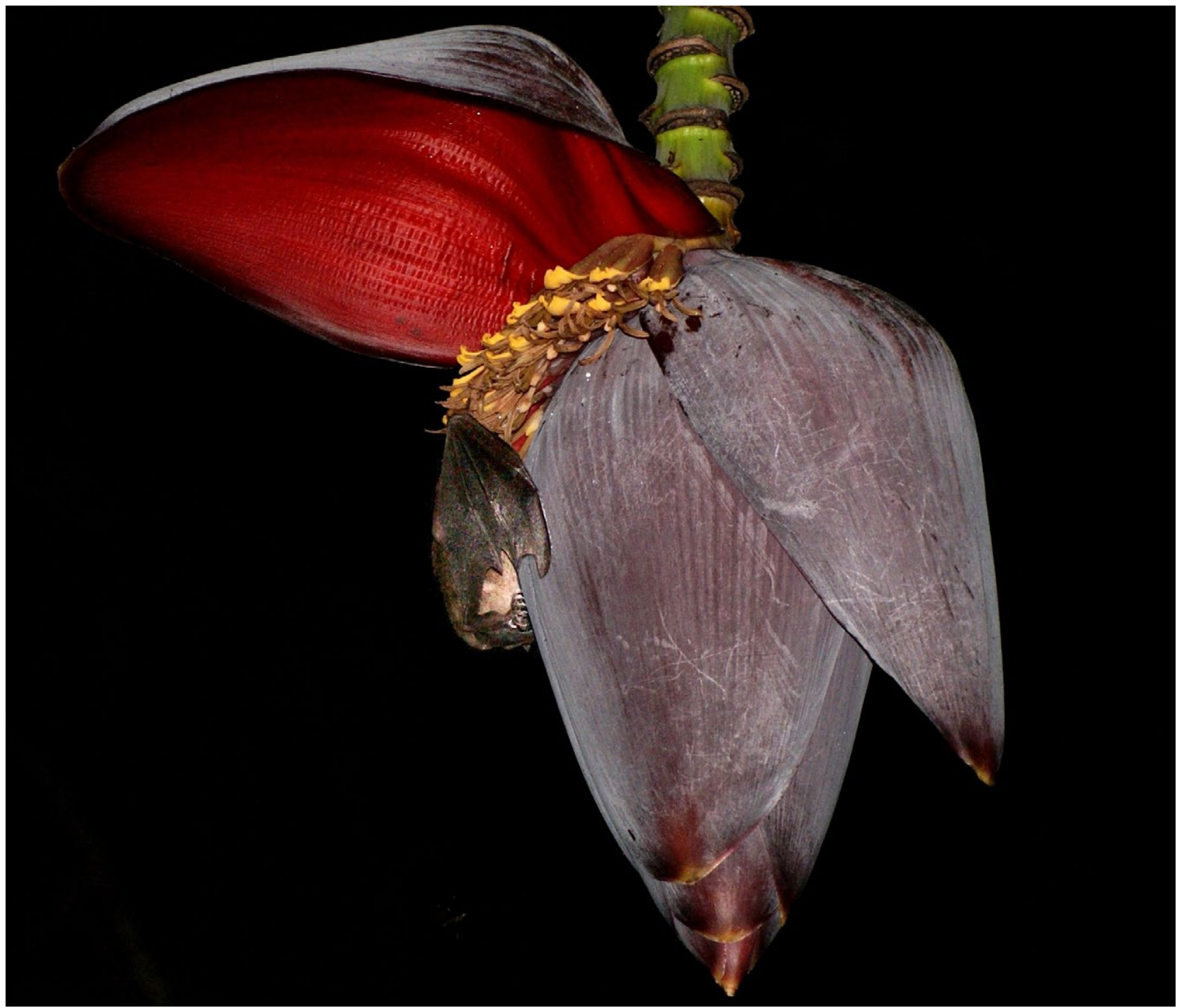

Fig. 2. Glossophaga soricina (Pallas, 1766) with its wings folded alongside the body performing the upside landing strategy on the banana inflorescence in an orchard located in the state of São Paulo, Brazil. Photo: Wilson Uieda.

with the hovering strategy being more used on plant species with delicate flowers and the landing strategy being more used on plant species with robust flowers. For example, G. soricina using the upside landing performs more than $85 \%$ and $75 \%$ of its visits in flowers of Thunbergia grandiflor Roxb. (Acanthaceae) and Cereus atroviridis Backeb. (Cactaceae) respectively, and zero and $35 \%$ in flowers of Calliandra laxa (Willd.) Benth. (Fabaceae) and Agave desmetiana Jacobi (Asparagaceae) respectively (LEMKe, 1984). The use of this strategy is a way to save energy in comparison to the expensive hovering (WINTER et al., 1993; VOIGT \& WINTER, 1999; TSCHAPKA \& DRESSLER, 2002) and can increase the success of detectability and extraction of nectar from flowers (NICOLAY \& WinTER, 2006) because bats take more time on them without being flying. In case of banana inflorescences, bats can easily extract nectar from more than one flower in only one visit as observed in the study orchard.

Downside landing is characteristic behavior of larger bats (Heithaus et al., 1974; SAZima et al., 1999; Silva \&
Peracchi, 1999; Fleming et al., 2009), such as P. discolor which has forearm length ranging from 58 to $64 \mathrm{~mm}$ and body mass of approximately $40.5 \mathrm{~g}$ in the study region (data from specimens sampled in the study area and surroundings; Pedrozo et al., 2016). In Costa Rica, Giannini \& Brenes (2001) observed this same behavior in $P$. discolor and $P$. hastatus during the visits to banana inflorescences in flight cage. Landing on flower or inflorescence by Phyllostomus species is possible, as these floral parts are strong enough to support their body mass (GIANNINI \& BRENES, 2001). Visiting behavior of Phyllostomus, in which the wings remain open (Heithaus et al., 1974; Sazima \& Sazima, 1977; Silva \& Peracchi, 1995; Giannini \& BRenes, 2001; present study), may be a way to maintain the balance on inflorescence, and to facilitate flying away from the inflorescence. In the present study, no visit of $P$. hastatus to $M$. paradisiaca inflorescences was videotaped, however, one individual was mist-netted near a banana plant on July $26^{\text {th }}, 2011$. The consumption of banana nectar by $P$. hastatus has been previously recorded 


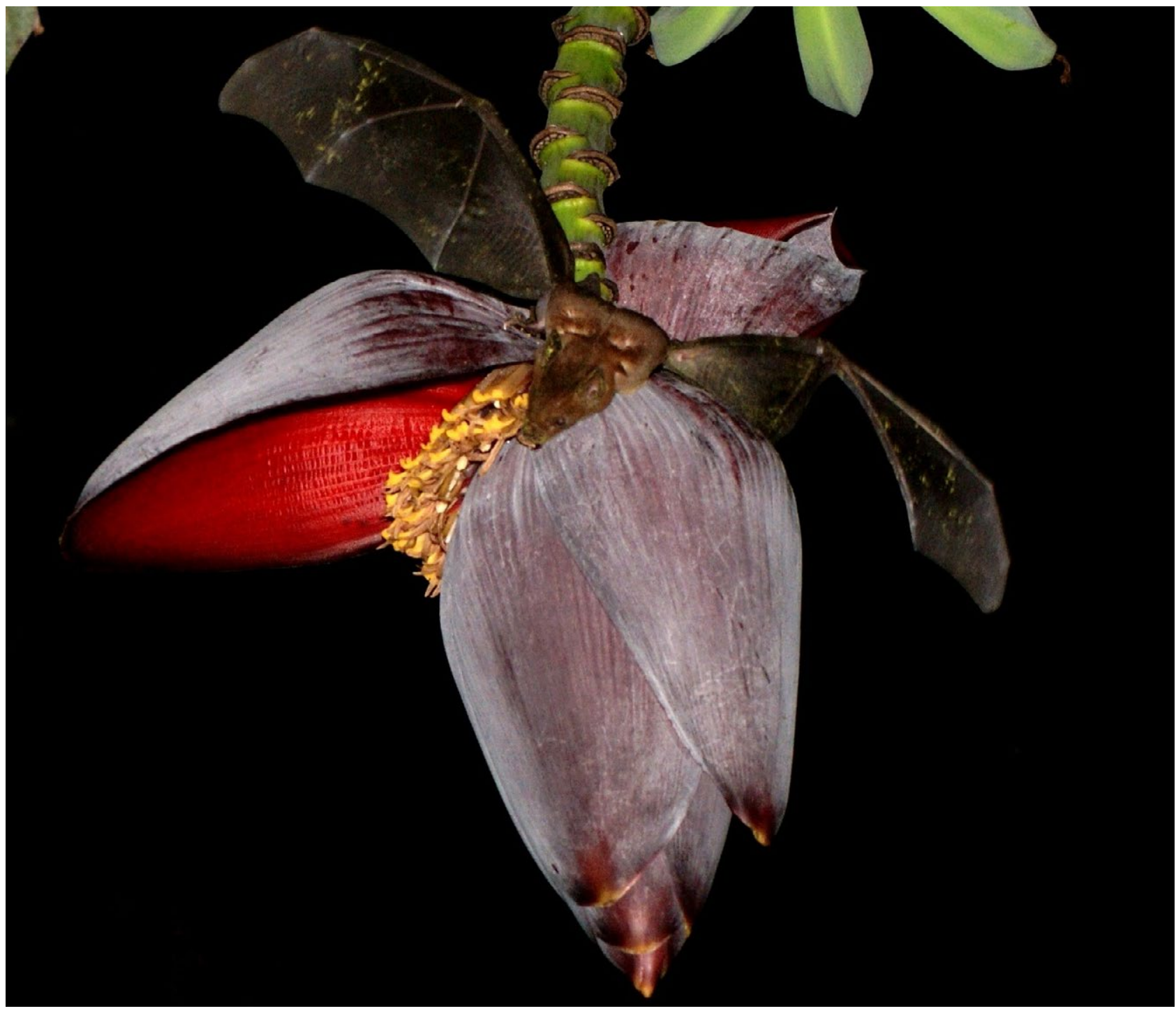

Fig. 3. Phyllostomus discolor (Wagner, 1843) with its wings completely open and its head directed toward the flowers performing the downside landing strategy on the banana inflorescence in an orchard located in the state of São Paulo, Brazil. Photo: Wilson Uieda.

by SiLva et al. (1997), GianNini \& Brenes (2001), BREDT et al. (2012), and Luz et al. (2015).

ElangOvan et al. (2000) and Liu et al. (2002) showed that a banana flower produces nectar for up to $28 \mathrm{hs}$ after the opening of bract. Although the nectar production in banana plants has not been measured in the study orchard, observations of insects (bees and beetles) and birds visiting the available flowers during the day time and bats visiting during the night time on the same day (personal observation) support steady nectar production by $M$. paradisiaca. Moreover, the nectar that was running from available flowers to dripping in the distal part of closed bracts, where it was seen a glossophagine performing a new feeding behavior of hovering and licking the nectar, also indicates steady nectar production. According to BOBROwIEC \& OlIVEIRA (2012), nectar production in some plant species can be induced by increasing of its removal by consumers.
Nectar-feeding bats that forage individually, as in the present study, or in few individuals (Heithaus et al., 1974; SilVA \& PERACCHI, 1995) tend to feed on the same flowers many times during the night by trapline route (SAzIMA et $a l ., 1999)$ and present territorial behavior avoiding visits of other bats (LEMKE, 1984). This foraging strategy of the glossophagines explains the lower number of mist-netted bats in comparison to the number of videotaped bats in the study orchard, indicating that there were few individuals foraging in this place. Furthermore, as we expected, the highest number of observations of these bats in the first part of the night might have occurred due to their high level of dietary specialization in nectar which is available in higher amounts in this period by flowers (e.g. AgUIAR \& MARINHOFILHO, 2004). Nectar production peaks during the first part of the night were also observed in other species of Musa (Itino et al., 1991; ElANGOVAN et al., 2000; Liv et al., 2002). 

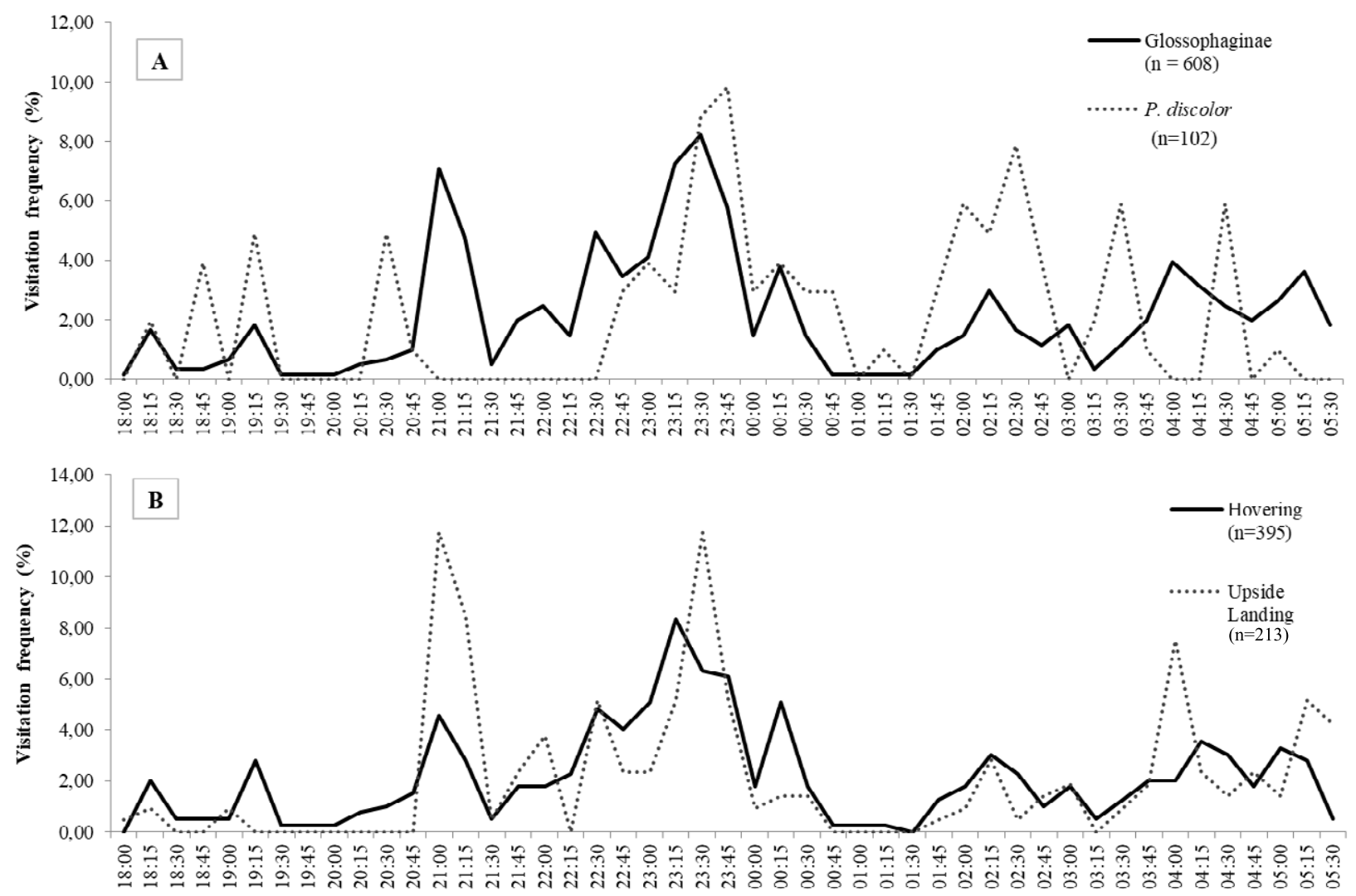

Fig. 4. Activity period of (A) two glossophagine species (Anoura caudifer + Glossophaga soricina) and Phyllostomus discolor on Musa paradisiaca inflorescence, and of (B) two approaching strategies (upside landing and hovering) performed by two glossophagine species in an orchard located in the state of São Paulo, Brazil.

Despite presenting solitary flights in the present study, P. discolor normally forages in group (HeITHAus et al., 1974). This species feeds opportunistically on nectar (TsCHAPKA \& DRESSLER, 2002) having no relationship between its abundance and banana inflorescences (e.g. LuZ et al., 2015). In the study orchard, $P$. discolor was more mist-netted than observed in videotaping due to its foraging strategy that enabled the search for other kinds of food supply. Piperaceae and Solanaceae seeds and insect fragments were found in feces of this species in the study area (PEDrozo et al., 2016). Moreover, there are other fruit plants besides banana, as jabuticaba, guava and mango, in the orchard that serve as potential food choices for $P$. discolor. This food supply also explainsits activity peak both in the first part and in the second part of the night in the present study.

Acknowledgements. We thank Antony Carioba for the permission to access and use the farm infrastructure to conduct this study; Flavio Kulaif Ubaid for the invitation and assistance in field; colleagues Moisés Guimarães, Elka Waiderman and Gabriel Mendes for assistance in the field activities; and Elza Guimarães for assistance in the botanical part of the study. LACG thanks the Brazilian fostering agency "Coordenação de Aperfeiçoamento de Pessoal de Nível Superior" (CAPES) for the $\mathrm{PhD}$ scholarships. The captures of bats were authorized by the Brazilian environmental agency ICMBio/IBAMA under process number 23151-1.

\section{REFERENCES}

Aguiar, L. M. S. \& Marinho-Filho, J. 2004. Activity patterns of nine phyllostomid bat species in a fragment of the Atlantic Forest in southeastern Brazil. Revista Brasileira de Zoologia 21(2):385-390.

BAKER, H. G. 1961. The adaptation of flowering plants to nocturnal and crepuscular pollinators. The Quarternary Review of Biology 36(1):64-73.

Bobrowiec, P. E. D. \& Oliveira, P. E. 2012. Removal effects on nectar production in bat-pollinated flowers of the Brazilian Cerrado. Biotropica 44(1): $1-5$.

Bredt, A.; Uieda, W. \& Pedro, W. A. 2012. Plantas e morcegos, na recuperação de áreas degradadas e na paisagem urbana. Brasilia, Rede de Sementes do Cerrado 273p.

Carvalho, C. T. 1961. Sobre os hábitos alimentares de Phillostomídeos (Mammalia, Chiroptera). Revista de Biologia Tropical 9(1):53-60.

Elangovan, V.; Marimuthu, G. \& Kunz, T. H. 2000. Nectar feeding behavior in the short-nosed fruit bat Cynopterus sphinx (Pteropodidae). Acta Chiropterologica 2(1):1-5.

ENDRESS, P. K. 1995. Diversity and evolutionary biology of tropical flowers. Cambridge, Cambridge University Press. 511p.

EsBÉRARD, C. E. L. 2007. Influência do ciclo lunar na captura de morcegos Phyllostomidae. Iheringia, Série Zoologia 97(1):81-85.

FAEGRI, K. \& VAN DER PIJL, L. 1979. The principles of pollination ecology. 3ed. London, Pergamon Press. 244p.

FisCHER, E. A. 1992. Foraging of nectarivorous bats on Bauhinia ungulata. Biotropica 24(4):579-582

Fleming, T. H.; Geiselman, C. \& Kress, W. J. 2009. The evolution of bat pollination: A phylogenetic perspective. Annals of Botany 104:10171043. 
Gardner, A. L. 1977. Feeding Habits. In: Baker, R. J.; Jones, J. K. \& CARTER, D. eds. Biology of bats of the New World Family Phyllostomatidae. Part II. Lubbock, Texas, Special Publications Museum Texas Tech University, p. 293-350

Gardner, A. L. 2007. Order Chiroptera. In: Gardner, A. L. ed. Mammals of South America. Volume 1: Marsupials, xenarthrans, shrews, and bats. Chicago, University of Chicago Press, p. 187-484

GianNini, N. P. \& BRENES, F. J. 2001. Flight cage observations of foraging mode in Phyllostomus discolor, P. hastatus, and Glossophaga commissarisi. Biotropica 33(3):546-550.

Gonzalez-Terrazas, T. P.; Medellin, R.A.; Knornschild, M. \& TsCHAPKA, M. 2012. Morphological specialization influences nectar extraction efficiency of sympatric nectar-feeding bats. Journal of Experimental Biology 215:3989-3996.

Gould, E. 1978. Foraging behavior of Malaysian nectar feeding bats. Biotropica 10(3):184-193

Hammer, R.; Harper, D. A. T. \& Ryan, P. D. 2001. PAST: Paleontological Statistics Software Package for Education and Data Analysis. Palaeontologia Electronica 4: 1-9.

Heithaus, E. R.; Fleming, T. H. \& Opler, P. A. 1975. Foraging patterns and resource utilization in seven species of bats in a seasonal tropical forest. Ecology 56(4):841-854.

Heithaus, E. R.; Opler, P. A. \& Baker, H. G. 1974. Bat activity and pollination of Bauhinia pauletia: plant-pollinator coevolution. Ecology 55(2):412-419.

Itino, T.; Kato , M. \& Hotta, M. 1991. Pollination ecology of the two wild bananas, Musa acuminata subsp. halabanensis and $M$. salaccensis: chiropterophily and ornithophily. Biotropica 23(2):151-158.

Kovach, W. L. 2011. Oriana - Circular statistics for windows, ver. 4 Pentraeth, Wales, UK, Kovach Computing Services.

LEMKE, T. O. 1984. Foraging ecology of the long-nosed bat, Glossophaga soricina, with respect to resource availability. Ecology 65(2):538-548.

LiU, A.; Li, D.; Wang, H. \& Kress, W. J. 2002. Ornithophilous and chiropterophilous pollination in Musa itinerans (Musaceae), a pioneer species in tropical rain forests of Yunnan, southwestern China. Biotropica 34(2):254-260.

Luz, J. L.; Costa, L. M. \& EsBÉrARD, C. E. L. 2015. Variação de recursos alimentares e abundância de morcegos em plantações de banana. Oecologia Australis 19(1):244-260.

Muller, M. F. \& ReIs, R. N. 1992. Partição de recursos alimentares entre quatro espécies de morcegos frugívoros (Chiroptera, Phyllostomidae) Revista Brasileira de Zoologia 9(3/4):345-355

Murphy, M.; Clare, E. L.; Rydell, J.; Yovel, Y.; Bar-On, Y.; Oelbaum, P. \& Fenton, M. B.2016. Opportunistic use of banana flower bracts by Glossophaga soricina. Acta Chiropterologica 18(1):209-213.

Nicolay, C. W. \& Winter, Y. 2006. Performance analysis as a tool for understanding the ecological morphology of flower visiting bats. In:
Zubaid A.; McCraken, G. F. \& Kunz, T. H. ed. Functional and Evolutionary Ecology of Bats. New York, Oxford University Press, p. 131-144.

Nur, N.1976. Studies on pollination in Musaceae. Annals of Botany 40(2):167-177.

Pedrozo, A. R.; Gomes, L. A. C.; Guimarães, M. \& Uieda, W. 2016. Quiropterofauna da Fazenda Santo Antônio dos Ipês, Jaú, estado de São Paulo, Brasil. Biotemas 29(1):97-107.

Pianka, E. R. 1973. The structure of lizard communities. Annual Review of Ecology and Systematics 4:53-74.

SAzIMA, I. \& SAzIma, M. 1977. Solitary and group foraging: two flowervisiting patterns of the lesser spear-nosed bat Phyllostomus discolor. Biotropica 9(3):213-215.

SAZIMA, M. \& SAZIma, I. 1978. Bat pollination of the passion flower, Passiflora mucronata in southeastern Brazil. Biotropica 10(2):100-109.

Sazima, M.; Buzato, S. \& SAZIma, I. 1999. Bat-pollinated flower assemblages and bat visitors at two Atlantic Forest sites in Brazil. Annals of Botany 83:705-712.

Silva, S. S. \& Peracchi, A. L. 1995. Observação da visita de morcegos (Chiroptera) às flores de Pseudobombax grandifolium (Cav.) A. Robyns. Revista Brasileira de Zoologia 12(4):859-865.

Silva, S. S. \& Peracchi, A. L.1999. Visit of bats flowers of Lafoensia glyptocarpa Koehne (Lythraceae). Revista Brasileira de Biologia 59(1):19-22.

Silva, S. S.; Peracchi, A. L. \& Aragẽo, A. O. 1997. Visita de Glossophaga soricina (Pallas, 1766) às flores de Bauhinia cupulata Benth (Leguminosae, Caesalpinoideae). Revista Brasileira de Biologia 57(1):89-92.

TschapKa, M. 2003. Pollination of the understorey palm Calyptrogyne ghiesbreghtiana by hovering and perching bats. Biological Journal of The Linnean Society 80:281-288.

TSCHAPKA, M. \& DRESSLER, S. 2002. Chiropterophily: On bat-flowers and flower bats. Curtis's Botanical Magazine (Serie 6):114-125.

TschapkA, M.; Gonzalez-Terrazas, T. P. \& KNORNSChILd, M. 2015. Nectar uptake in bats using a pumping-tongue mechanism. Science Advances 1:1-5.

Voigt, C. C. \& Winter, Y. 1999. Energetic cost of hovering flight in nectarfeeding bats (Phyllostomidae: Glossophaginae) and its scaling in moths, birds and bats. Journal of Comparative Physiology B 169:38-48.

Winter, Y. \& von Helversen, O. 2003. Operational tongue length in phyllostomid nectar-feeding bats. Journal of Mammalogy 84:886-896.

Winter, Y.; von Helversen, O.; Norberg, U. M.; Kunz, T. H. \& SteFFensen, J. F. 1993. Flight cost and economy of nectar-feeding in the bat Glossophaga soricina (Phyllostomidae: Glossophaginae). In: Barthlott, W.; Naumann, C.; Schmidt-Loske, K. \& Schumann, K. L. eds. Plant-animal interactions in tropical environments. Bonn, Museum Alexander Koenig, p. 167-174. 